\title{
Analysis of Edward Bond's War plays
}

\author{
Amir Daneshzadeh
}

\author{
Corresponding Author: Amir_daneshzadeh1347@yahoo.com
}

\section{Keywords: Analysis of Edward Bond's}

\begin{abstract}
The War Plays'trilogy (Red, Black and Ignorant, The Tin Can People and Great Peace) presents the scenario of a waste land 'with apocalyptical shades. The post nuclear environment of the plays reflects the Atmosphere of the historical period when it was written. The beginning of the eighties saw the debate about nuclear weapons and strong discussions about the Thatcher administration in this respect. Edward Bond emerged from a group of left-wing writers who joined the experimental fringe theatre in the 1970s. To make sense of this literature, we turn to content analysis to examine the trends and categorize the burgeoning management research of the past 25 years that uses content analysis. In Red Black and Ignorant characters confront the paradox. Society uses dramatists to create the drama it needs but a dramatist is not a conduit. $\mathrm{He}$ is responsible for what he writes, not out of duty but because discerning anything means evaluating it and this requires desire and commitment. What an author writes expresses the political position that informs his subjectivity. The way he writes shows his relation to himself, which is also his part in the social process. The relation 'creates' what he writes, the limitations come from the limitations of his skill.
\end{abstract}

\section{INTRODUCTION}

Edward Bond emerged from a group of left-wing writers who joined the experimental fringe theatre in the 1970s. His daunting debates about moral standards, as well as the stylistic pluralism of his plays, constitute the distinguishing features of 'a new theatre' whose intended purpose has been viewed as an attack on British complacency. Bond is expert at creating surprising theatrical metaphors that are acted out in a direct way in order to materialize the evils of society, namely, 'what society does when it is heavy with aggression'. As the dramatist is firmly committed to humanistic values, he enjoys protesting against social and political injustice in a loud voice. Like his German predecessor, Bertolt Brecht, Bond is concerned with orienting the audience toward reflection rather than emotional contemplation of the stage incidents. As he has put it:

"Theatre is a way of judging society and helping to change it; art must interpret the world and not merely mirror it. (Notebooks of Edward Bond, volume 1, page 34)."For that reason his work lays emphasis on the contradictions of a class-structured society, disclosing its destructive effects on individuals and drawing attention to the impossibility of any social improvement as long as political action is ineffective (1).

Edward Bond's trilogy of plays portrays a brutal world struggling in the aftermath of nuclear holocaust. The War Plays trilogy contains three of Bond's mid-eighties works. In all three plays, Bond wrestles with an imagined nuclear holocaust. In Red Black and Ignorant, a family is torn apart by a futuristic police state in the days before the bombs begin falling. The play explores issues of conformity, social morality and chronic conflict between individual and society, thus losing nothing of its relevance with time.

Bond's technique of using small exchanges between families and communities as a lens to explore larger political concerns via short, episodic scenes instantly reminded us of Brecht's Fear and Misery in the Third Reich. It features a son forced into military service struggling with an order to kill within their community. Several gut-wrenching scenes of Mothers struggling to save child from state-ordered death evoke another Brecht classic: The Caucasian Chalk Circle.

Red Black and Ignorant introduces Monster, an inhuman being who presents the life that he did not get to live. Killed within his mother's womb, the play reveals the world which would have awaited the unborn child: a post-apocalyptic society of destruction and war. Bond calls him 
Monster, though he seems a caring humane individual, and he would appear to be that baby burned at birth. The monster as a narrating character introduces and embodies the historicizing nature of the play as it makes itself felt through shifts in time, allusions to past cultures, action and direct address. In the opening monologue, he invokes a series of images that establishes a biological, cultural, and historical connection to the past as well as a radical break.

The play is accompanied by Bond's commentary on the processes of improvisation and experimentation, providing a comprehensive discussion of the playwright's theoretical approach to his work, thus it presents itself as both a lesson and a practice session that arms the audience to correctly interpret and better understand the plays that follow.

Subject of nuclear war for the play, its causes and effects, would be a useful political intervention, perhaps providing a perspective for people (like myself) who find themselves disorientated by the threat of nuclear annihilation. The play offers a forty-five minute series of short sketches 'Learning', 'Love', 'Eating', 'Selling', 'Work', 'The Army', 'No one can willingly give up the name human', and 'Funeral' -- which, as 'The Introduction' (the first scene) explains, tell us the histories of our times. The play characterized by unrelenting descriptions of pain and horror. I believe they are an attempt to produce what Howard Barker has recently characterized as modern tragedy -- pain rather than comfort, a pain which may 'equip us against lies'. Bond has repeatedly questioned the rationality of a society 'in which the audience can sit in the theatre while a few miles along the road men are sitting before gadgets that fire nuclear weapons' and he said that here he wanted 'to show the psychosis that exists after a nuclear war'. The result is an unrelenting surreal and expressionistic language. Bond is 'writing the first tenuously optimistic bomb plays and suggesting that out of the ashes a new order may come'. The play is not just about a psychotic survival after the bomb but the building of a new and just society, but Ernest Mandel has argued the absurdity of such notions of 'socialism out of the ruins', pointing out that a nuclear war would destroy the considerable human and technical resources necessary for building a classless society. In the 'best case' scenario it would not be socialism that arose from the nuclear ashes but barbarism from which the survivors could advance only in an arduous centuries-long ascent. Bond wrote: 'A society which does not "know itself", does not act rationally. If the processes by which the state organizes society's various strata and activities are corruptions of the truth, then these corruptions will affect all its decisions, little and great'. In the nuclear age, he says, unless our thinking changes, then we are already dead. Throughout the trilogy Bond's analysis fuses the future with the present but it is most fully developed in Red, Black and Ignorant. The play opens with a character called 'The Monster' who declares that 'in the past children thought the world was watched over by gods/but now we kill them. He continues with descriptions of the nuclear apocalypse, and we learn that his monstrosity was caused by his being born in the midst of it. The scene ends with him saying that the audience are about to see scenes from the life we did not live, i.e., by implication from the life we are still living. These scenes stress the connection between our present way of life and postnuclear existence, showing the origins of The Monster to lie essentially in our own time. Thus in Scene Two education is described in terms of a fiery baptism: 'In lessons a blowtorch ran over my body/my nerves are burned out so I felt no pain', and later, 'A bullet has passed from side to side of my brain. The other scenes in the play attempt to show how all aspects of our way of living foster an irrationality which will turn the imagined holocaust which opens the play into a reality. 'The Wife' concludes in the final scene: You who live in barbarous times Under rulers with redness on their hands, blackness in their hearts and ignorance in their minds Everything before your time was the childhood of humankind With the new weapons that age passed But you went on building your house with bricks that were already on fire. In these plays Bond is saying that capitalism in general, and nuclear weapons in particular, already make us dead. They are all so excruciatingly abstract and the images are contrived and forced. The Monster's ravings about the gods looking over children and then the earth whistling in derision is sentimental, and The Monster's charred state -- a physical reminder throughout the play of the way we treat children -- can shock without generating understanding. Bond is using the imagery of nuclear war and its consequent degradation as a way of passing comment on the state of the world now. Bond's images resemble a private nightmare to 
which we have 'privileged' access. The most fundamental weakness of the Play is that is undramatic. Instead of concrete characters and situations there are a series of intellectual abstractions, a kind of 'symbolic logic' for the stage. However, as Peter Brook has advised, 'we cannot assume that the audience will assemble devoutly and attentively. It is up to us to capture its attention and compel its belief'.

Edward Bond, wrote "Violence shapes and obsesses our society, and if we do not stop being violent we have no future. People who do not want writers to write about violence want to stop them writing about us and our time. It would be immoral not to write about violence." This talk will explore how Bond stages violence in three of his early plays. The plays grew out of an improvisation which Bond conducted at the University of Palermo in Sicily in which he asked the students to imagine themselves as soldiers given the choice of killing a stranger or their own brother. All the students chose their brother.

The play uses historical time horizontally, but psychological time vertically: the passing of one time through the other theater events plays. Even if they are played on their own the plays will still be seen as theater events because that is how they are written. The audience gives the meaning - they have the role the Greek theatre still kept on stage and gave to the Gods.

In Red Black and Ignorant the soldier returns home with his order to kill someone - anyone in the neighbourhood. His mother represses her revulsion, dresses him in his uniform and sends him to kill her neighbour. The text gives her and her son's reasons for what they do. They may have other motives in a subtext (perhaps a writer is not always in control of the subtext). Does the son have an oedipal relation to the father so that already he wants to kill him (as in the end he does) instead of the neighbour? Could it be unconscious guilt that makes him stand as passively as a child being dressed to run an errand?

The text (and any subtext) is written but a metatext is not. It is inferred and created by studying and rehearsing the written texts. It may contain many ideas, actions and emotions because it is open-ended - and some of these may already be in the written text. The neighbour is a friend and the mother does not want him killed - that is text and subtext. But some things will only be in the metatext. Years ago when the mother sent her son on errands was she already training him in the obedience a soldier needs when he kills? In a way, when a soldier kills314he is running an errand for his officers. That is a metatext question because it touches on the nature of society. The metatext of Red Black and Ignorant says that it takes a lot of culture to make us killers. An Oedipal subtext would not explain what happens, any more than that we breathe tells us why we drown. What is relevant is not the motive but the cause. That is found by philosophic analysis of society. The truth is in the social world and in the metatext. Obviously that is what the acting should show in action, gesture, texture - if it is to show the incident's truth. In this scene neither the mother nor son act on their motivations, they react to the officer as if he were Fate. The meanings provided by the subtext and the metatext are radically different. It is not a difference of artistic sensibility or taste. Apart from acts of radical innocence, the meanings of our acts are never our motivations for doing them. The reasons for our acts come from society. We act as we do because we are in a particular sort of society. Acts are like moves in a game: the rules of the game give the meanings of the moves and players move according to the rules. The Plays' philosophy is socialist, that is, it is written in the understanding that there could be no reason in the subtext why the soldier must kill anyone. The incident's truth is in the metatext. That does not restrict the interpretation or make it doctrinaire. The subtext would be restrictive because its explanation is closed and invites pathos, which our age makes maudlin (as in Beckett's messenger boy and Cocteau's 'Poor Oedipus!').

The reviews of the war play "Red, Black and Ignorant"

There are many books with anti-war theme. "Red, Black and Ignorant" is written by Edward Bond. Edward Bond depicts violence and the injustices of our world in all his plays since the sixties. The playwright is determinant in his criticism to the present drama far from reality and the needs of questions for society. Since the scandal of Saved in the sixties, Edward Bond has always argued the topic of violence in his plays. Bond's techniques are created not simply to depict the present but to make us critically aware of how and why we can respond to the past. Bond's 
treatment of history investigates about the possibilities of change in all his plays since history, for him, is a test to learn.

The War Plays'trilogy (Red, Black and Ignorant, The Tin Can People and Great Peace) presents the scenario of a waste land 'with apocalyptical shades. The post nuclear environment of the plays reflects the Atmosphere of the historical period when it was written. The beginning of the eighties saw the debate about nuclear weapons and strong discussions about the Thatcher administration in this respect. In 1983, Ian McEwan wrote about the fears of the common people in his famous book Or Shall We Die?

"I was struck by how deeply the lives of individuals had been shaken by the new cold war. People described the pointlessness of planning ahead. And the creeping sense of the irrelevance of all things they valued against the threat of annihilation" (McEwan, 1983, 9). This is the feeling and the background of the trilogy but The War Plays seem more contemporary than ever. The two first parts of the trilogy set the scene and provide descriptions of horrors after nuclear bomb devastation. Starving people gorging in the ruins depict the extreme of consumerism. As Howard points out: "The Tin Can People are more than Bond's image of suicidal materialism; the play is given nauseating weight by their language, for it dwells remorselessly on the past; they are fixated with the dead and the physical horror of the catastrophe" (1996: 137). Bond depicts a horrific world in which humanity has disappeared after the nuclear disaster to the Point that characters are nameless: WOMAN, SOLDIER, SON or DAUGHTER. This dust land is presented as a kind of dead environment in which life should sprout. Bond points out: The characters are not named because although they are not symbols their lives are social forces -and the forces are clarified by the crises. But there is another reason. They have lost their names because they have lost themselves. Names are a sign of our humanity. In a nuclear age we still have to create our humanity (2002: 361). For Bond, the violence against the socially marginalized portrays the unjust system of our world.

"A baby's skull sticking out of the ground", it illustrates the dark and hazy environment of the society. Many kids are killed innocently and corpses are left on the ground sporadically. The violence of war is apparent in these scenes. Many diseases are dispread and people are afraid of losing their lives.

On stage, a somber and disheveled monster is presented to us. He confesses how he is the unborn and the future of a world in decline and on the edge of is own destruction. Mimicking the ghost of Christmas yet to come, he introduces visions of an as yet unrealized future, regnant with poverty, selfishness and war.

Couples are forced to sell off their only child. A young man leaves a friend to die, intent that it decreases the competition for work. There are recurring characters, but no obvious protagonist. Bodies move in and out a communal psychology. This is all highlighted by the benignant monster, a literary descendant of Frankenstein's, who we see misunderstanding society in the same way that Boris Karloff's interpretation once did. On its premiere, the first of Bond's War Plays contributed to a hysteric fin-de-siècle, throwing up questions of human morality and existence. Whilst the cold war and the fin-de-siècle have now passed, the play still has an eerie resonance. We are still in a state of paranoia - post $9 / 11$, post $7 / 7$, in a world where military intervention is a confirmed reality. Where the playwright succeeds is in recognizing a world obsessed with cultural competition. In Red, Black and Ignorant, Bond summarized the dystopian consequences of political lassitude years before Fujiyama had theorized 'The End of History'.

This production is at its best in its starker moments where the small stage encloses and builds new intensity. Yet, the condensing of action to such a fixed point also cramps the drama and creates an oddly alienating effect. It does not quite break the fourth wall but instead creates an almost televisual quality with the illusion being of the play within a cathode ray tube, projected at the foot of the stalls. It diminishes the play's effect, numbing the audience to the events before them and, rather than being drawn in by the revulsion, we become unable to contextualize the horror. The Cock Tavern Theatre's is a thought provoking, impacting production; it is right and appropriate that they revive it now. But as for a message, we are left guessing. 
Whilst a play does not need a moral, it deserves a clearer message should the playwright obsess himself with such bleak and politicized work as Bond does. But in the case of Red, Black and Ignorant, we are instead presented only with a collection of failed ethics and intentions. What we receive is a relentless beating around the scalp; shaking and unnerving but offering no assurances and no recommendations. When the lights came up at the performance I attended, the audience left in silence.

In The Tin Can People, a community of survivors is living on tinned food, years after the nuclear explosion. When a stranger appears, he is welcomed into the group, but suspicions mount when one of the other survivors dies. Convinced that the newcomer is contaminated, the group resolves to destroy this new threat to their existence. A woman descends into madness in Great Peace after her baby is murdered by her son on military orders. She is adopted by a new community who offer to care for her but rather than accept their welcome; she ultimately chooses to stay in the wilderness.

The starting point of Great Peace is based on a paradox. A soldier returns home with orders to choose a baby from his street and kill it. Two babies live in his street: his mother's and a neighbour's but unexpectedly the soldier kills his mother's child.

Bond points out: The characters are not named because although they are not symbols their lives are social forces -and the forces are clarified by the crises. But there is another reason. They have lost their names because they have lost themselves. Names are a sign of our humanity. In a nuclear age we still have to create our humanity $(2002,361)$.

The tragedy of Woman in the play becomes the traumatic acceptance of the killing of her son by his own brother. This dilemma with Herodian traces provides the opportunity to begin a journey to social conscience. The reversal of the expected killing blurs the boundary between inside (family) and outside (stranger) as a deconstruction technique. Bond suggests a more humanitarian concept of maternity beyond blood ties; a definition of a social mother. The Woman becomes the guide of the audience in a journey to sanity through madness in this wilderness scenario.

Different outsiders along her evolution will force her to confront her implication in the killing of her baby and the need to change the reduced concept of family to a broader nucleus.

Through a wasteland of radiation and a nuclear winter, the end of the World becomes the new landscape on stage. Absolutely traumatized by her son's action, Bond's Woman is discovered wandering alone, ragged with a false baby. The creation of the bundle stands as the central image of Great Peace and the clear representation of her dead baby. In an endless solitude, all her hope is concentrated on receiving a sign of life from the bundle and fantasies with its voice as her last possibility to survive. In a series of parable episodes, the Woman meets other survivors but in this bare desert relationships remain silent only forced by hunger and robbery. The central scene of the play narrates the encounter between the woman and Pemberton, a colleague soldier of her son. Pemberton, the only name in Great Peace, forms part of a group of soldiers with filthy uniforms and rags. They believe they are dead but still pound human bones into soup in an inexplicable need of survival: "The SOLDIERS go into a dry hard hysteria. Each stays shut him. They rock their bodies and cry into the ground- they glance at each other only once or twice" (Bond, 2002, 171).

\section{References}

[1] Bond Edward. 2000-20001. Notebooks of Edward Bond. London: Methuen

[2] Lon Bond, Edward, The War Plays: A Trilogy. London: Methuen, 1985. Print. don Ltd

[3] Owens, Patricia. "Violence and Power, Politics and War." Between War and Politics (2007): 13-32. Web.

[4] Byrne, Rhonda. The Power. New York: Atria, 2010. Print.

[5] Thompson, James A. Psychological Aspects of Nuclear War. Chichester: British Psychological Society and J. Wiley, 1985. Print.

[6] Trussler, Simon, and Ian Scott-Kilvert. Edward Bond. Harlow: Published for the British Council by Longman, 1976. Print.

[7] Methuen Contemporary Dramatists. London: Methuen, 1993. Print. 
[8] Schinkel, Willem. Aspects of Violence: A Critical Theory. Basingstoke: Palgrave Macmillan, 2010. Print.

[9] Ku, Kelly Y.1. "Assessing Students' Critical Thinking Performance: Urging for Measurements Using Multi-response Format." Thinking Skills and Creativity 4.1 (2009): 70-76. Web.

[10] Barcus, Francis Earle. Communications Content Analysis of the Research, 1900-1958: A Content Analysis of Content Analysis. N.p.: n.p., 1959. Print.

[11] Sanyal, Debarati. The Violence of Modernity: Baudelaire, Irony, and the Politics of Form. Baltimore: Johns Hopkins UP, 2006. Print.

[12] Thompson, James A. Psychological Aspects of Nuclear War. Chichester: British Psychological Society and J. Wiley, 1985. Print.

[13] oney, June. Aspects of War: Evacuation, Deportations, Liberation, Communications, Transport, Fuel. St Peter Port: J.P. Money, 1995. Print.

[14] Owens, Patricia. "Violence and Power, Politics and War." Between War and Politics (2007): 13-32. Web. 